\title{
Uncertainties in selected river water quality data
}

\author{
M. Rode and U. Suhr \\ UFZ - Helmholtz Centre for Environmental Research, Department of Hydrological Modelling, Brueckstrasse 3a, 39114 \\ Magdeburg, Germany
}

Received: 24 February 2006 - Published in Hydrol. Earth Syst. Sci. Discuss.: 21 September 2006

Revised: 13 December 2006 - Accepted: 1 February 2007 - Published: 13 February 2007

\begin{abstract}
Monitoring of surface waters is primarily done to detect the status and trends in water quality and to identify whether observed trends arise from natural or anthropogenic causes. Empirical quality of river water quality data is rarely certain and knowledge of their uncertainties is essential to assess the reliability of water quality models and their predictions. The objective of this paper is to assess the uncertainties in selected river water quality data, i.e. suspended sediment, nitrogen fraction, phosphorus fraction, heavy metals and biological compounds. The methodology used to structure the uncertainty is based on the empirical quality of data and the sources of uncertainty in data (van Loon et al., 2005). A literature review was carried out including additional experimental data of the Elbe river. All data of compounds associated with suspended particulate matter have considerable higher sampling uncertainties than soluble concentrations. This is due to high variability within the cross section of a given river. This variability is positively correlated with total suspended particulate matter concentrations. Sampling location has also considerable effect on the representativeness of a water sample. These sampling uncertainties are highly site specific. The estimation of uncertainty in sampling can only be achieved by taking at least a proportion of samples in duplicates. Compared to sampling uncertainties, measurement and analytical uncertainties are much lower. Instrument quality can be stated well suited for field and laboratory situations for all considered constituents. Analytical errors can contribute considerably to the overall uncertainty of river water quality data. Temporal autocorrelation of river water quality data is present but literature on general behaviour of water quality compounds is rare. For meso scale river catchments $\left(500-3000 \mathrm{~km}^{2}\right)$ reasonable yearly dissolved load calculations can be achieved using biweekly sample frequencies. For suspended sediments none of the methods inves-
\end{abstract}

Correspondence to: $\mathrm{M}$. Rode

(michael.rode@ufz.de) tigated produced very reliable load estimates when weekly concentrations data were used. Uncertainties associated with loads estimates based on infrequent samples will decrease with increasing size of rivers.

\section{Introduction}

The objective of this paper is to give an overview of the uncertainties in selected river water quality data. Monitoring of river quality is primarily done to detect the status and trends and to identify whether observed trends are due to natural or anthropogenic causes. Most important environmental problems in river water quality are eutrophication, acidification and emission dispersion where non point source pollution has become increasingly important within the last decades. Eutrophication is not restricted to rivers. It is a world-wide environmental problem of inland and coastal waters and serious efforts are needed to reduce emissions and improve the situation (e.g., Ryding and Rast, 1989). The effect of eutrophication is high production of plankton algae ("algal blooms"), excessive growth of weeds and macroalgae, leading to oxygen deficiency, which in turn leads to fish kills, reduced biological diversity, bottom death and toxic substances in the water. The problems related to acidification are mainly found in the northern hemisphere, which are caused by air-born pollutants that result in acidic conditions when deposed on sensitive soils. Regarding dispersions of water-related pollutants, it may be important to assess accidental emissions or indirect side-effects. Regarding the marine environment reductions of nutrient and contaminant loads are primary objectives.

Beside the identification of the status and trends, river water quality data are essential for the application of stochastic and deterministic water quality models (Trudgill, 1995; Arheimer and Olsson, 2003). Water quality models are generally used to separate the contributions from various

Published by Copernicus GmbH on behalf of the European Geosciences Union. 
Table 1. Summary of selected river water quality variables.

\begin{tabular}{|c|c|c|}
\hline Variable & Abbreviation & Unit \\
\hline \multicolumn{3}{|l|}{ Sediments } \\
\hline $\begin{array}{l}\text { Suspended sediments, dried by } 103 \\
\text { to } 105^{\circ} \mathrm{C}\end{array}$ & Sed & $\mathrm{g} / 1$ \\
\hline \multicolumn{3}{|l|}{$N$-Fraction } \\
\hline $\begin{array}{lll}\text { Nitrate } & \text { (Cadmium } & \text { Reduction } \\
\text { Method) } & & \end{array}$ & $\mathrm{NO}_{3}-\mathrm{CRM}$ & $\mathrm{mg} / \mathrm{l}$ \\
\hline Nitrate (Electrode Method) & $\mathrm{NO}_{3}-\mathrm{EM}$ & $\mathrm{mg} / \mathrm{l}$ \\
\hline Nitrite $\left(\mathrm{IC}^{1}\right)$ & $\mathrm{NO}_{2}$ & $\mathrm{mg} / \mathrm{l}$ \\
\hline Ammonium (IC) & $\mathrm{NH}_{4}$ & $\mathrm{mg} / \mathrm{l}$ \\
\hline \multicolumn{3}{|l|}{ P-Fraction $(I C)$} \\
\hline Total Phosphorus & $\mathrm{TP}$ & $\mathrm{mg} / \mathrm{l}$ \\
\hline Particulate Phosphorus & $\mathrm{PP}$ & $\mathrm{mg} / \mathrm{l}$ \\
\hline Dissolved Phosphorus & DP & $\mathrm{mg} / \mathrm{l}$ \\
\hline Soluble reactive Phosphorus & SRP & $\mathrm{mg} / \mathrm{l}$ \\
\hline \multicolumn{3}{|l|}{ Biological Fraction } \\
\hline $\begin{array}{l}\text { Chemical oxygen demand (Potas- } \\
\text { sium dichromat) }\end{array}$ & COD & $\mathrm{mg} / \mathrm{l}$ \\
\hline $\begin{array}{l}\text { Biological oxygen demand }\left(\mathrm{O}_{2}\right. \\
\text { probe })\end{array}$ & BOD & $\mathrm{mg} / \mathrm{l}$ \\
\hline Chlorophyll-a (HPLC $\left.{ }^{2}\right)$ & Chl-a & $\mathrm{mg} / \mathrm{m}^{3}$ \\
\hline $\begin{array}{l}\text { Dissolved organic carbon (Heated } \\
\text { oxidation method) }\end{array}$ & DOC & $\mathrm{mg} / \mathrm{l}$ \\
\hline \multicolumn{3}{|l|}{ Heavy metals $\left(I C P-M S^{3}\right)$} \\
\hline Arsenic & As & $\mu \mathrm{g} / \mathrm{l}$ \\
\hline Chrome & $\mathrm{Cr}$ & $\mu \mathrm{g} / 1$ \\
\hline Copper & $\mathrm{Cu}$ & $\mu \mathrm{g} / 1$ \\
\hline Iron & $\mathrm{Fe}$ & $\mu \mathrm{g} / 1$ \\
\hline Mercury $\left(\mathrm{Cv}-\mathrm{AAS}^{4}\right)$ & $\mathrm{Hg}$ & $\mu \mathrm{g} / 1$ \\
\hline Manganese & $\mathrm{Mn}$ & $\mu \mathrm{g} / 1$ \\
\hline Lead & $\mathrm{Pb}$ & $\mu \mathrm{g} / 1$ \\
\hline Zinc & $\mathrm{Zn}$ & $\mu \mathrm{g} / 1$ \\
\hline
\end{tabular}

${ }^{1}$ Ion Chromatography

2 High-Performed Liquid Chromatography

${ }^{3}$ Inductively Coupled Plasma/Mass spectrometry

4 Cold-Vapor Atomic Absorption Spectrometric

sources and to distinguish between natural variability and anthropogenic impact. Predictive models are commonly used for integrating and testing of alternative management strategies. This enables an efficient environmental control and the development of management practices. Water quality modelling allows also the prediction of future scenarios.

Clearly, pollution and acidification are the most important reasons for past and current water quality model development. The pollution context includes models of the transport of nutrients, organic material, oxygen balance, heavy metals and organic compounds through soil profiles, hillslopes and catchment scale as well as the modelling of downstream changes in pollutant loading (James, 1993). Closely related to the pollution context is the simulation of soil erosion and sediment transport on the catchment scale. The group of river water quality models simulate the substance transformation in river channels in a mechanistic way and transport calculations are based on hydraulics. These models are able to simulate biological variables like primary production and the transport of pollutants like heavy metals and organic chemical (exposure models). The acidification context includes short and long-term models of chemical reactions catchment scale models. Most important variables are the $\mathrm{pH}$-value and related heavy metals as well as the Si-fraction. Knowledge of the uncertainties in river water quality data is essential to assess the reliability of water quality models and their predictions, e.g., scenario analyses.

Although previous research has produced valuable information on the uncertainty inherent in measured river water quality data, a systematic review to quantify important sources of uncertainties of river water quality data is missing. Most literature focus on selected aspects of data uncertainties like data collection (e.g. Harmel et al., 2006b), analysis of techniques quantifying and comparing different sources of uncertainties (e.g. Ramsey, 1998) or specific water quality variables like suspended sediments in sediment rich rivers (Horowitz, 1997). Only very view attempts have been made to characterise river water quality data uncertainties according to a specific uncertainty framework. Harmel et al. (2006a) used four procedural categories to assess streamflow water quality data uncertainties. The findings were restricted to nutrients and small streams. The objective of the present paper is to present a more general framework characterising uncertainties in river water quality data. The examples cover primarily the main stem of rivers.

\subsection{Selected groups of variables}

Monitored surface water quality variables are numerous. This is especially true for the group of organic chemicals; e.g. the Water Framework Directive defined 33 priority constituents and constituents groups. Therefore a selection of the most important water quality variables has to be made with special regard to modelling aspects. We selected the surface water quality constituents listed in Table 1 according to their importance, their behaviour and the model needs. Recent evidence indicates that the majority of fluvial trace element and some major ion transport occur in association with suspended sediments (Horrowitz, 1995, 1997). This is also true for organic chemicals with high adsorption coefficients. Furthermore, suspended sediments are important for total phosphorus transport in surface waters. Suspended sediments concentrations have extremely high spatial and temporal variability and are therefore associated with high sampling uncertainties. Nutrients like phosphorus, nitrogen and silicon are limiting constituents for primary production especially in large rivers and the marine environment. Primary production influences the oxygen concentrations and impacts also the $\mathrm{pH}$-value. Additionally, some inorganic nitrogen compounds have acute chronic effects on aquatic 
Table 2. Important sources of uncertainties of river water quality data.

\begin{tabular}{|c|c|c|c|c|}
\hline Field instruments & Sampling location & $\begin{array}{l}\text { Representative sam- } \\
\text { pling }\end{array}$ & Laboratory analysis & Load calculation \\
\hline Instrument errors & $\begin{array}{l}\text { Mixing of large tribu- } \\
\text { taries }\end{array}$ & $\begin{array}{l}\text { High spatial variation } \\
\text { within the cross sec- } \\
\text { tion }\end{array}$ & $\begin{array}{l}\text { Sampling conserva- } \\
\text { tion }\end{array}$ & Sampling frequency \\
\hline \multirow[t]{3}{*}{$\begin{array}{l}\text { Instrument calibration } \\
\text { errors }\end{array}$} & Point source inputs & $\begin{array}{l}\text { High temporal varia- } \\
\text { tion (e.g. due to point } \\
\text { source inputs, flood } \\
\text { events) }\end{array}$ & Sample transport & Sampling period \\
\hline & $\begin{array}{l}\text { Impoundments, dead } \\
\text { zones etc. }\end{array}$ & Sampling volume & Instrument errors & $\begin{array}{l}\text { Choice of extrapola- } \\
\text { tion method (e.g. rat- } \\
\text { ing curve) }\end{array}$ \\
\hline & & Sampling duration & $\begin{array}{l}\text { Laboratory induced } \\
\text { uncertainties }\end{array}$ & \\
\hline
\end{tabular}

organisms and are relevant for drinking water supply. Biological variables like BOD are the most important indicators for waste water emissions and highly affect oxygen concentrations. Chlorophyll a, which is commonly used as an indicator for algal biomass, is also relevant for drinking water supply from surface waters. Biological variables are highly variable in space and time and are associated with high sampling and analytical uncertainties.

The objective of this paper is to assess the uncertainties in selected surface water quality data, i.e. suspended sediment, nitrogen fraction, phosphorus fraction, heavy metals and biological compounds. The considered variables in this chapter are listed in Table 1. For each variable the most commonly used analytical method was selected. They can be grouped into sediments, nutrients (mainly nitrogen and phosphorus compounds), biological variables, selected major ions and trace elements (see Sect. 2). Due to the importance of the calculation of river load and the large uncertainties associated with different calculation procedures one section on this topic is added. All constituent sections consider information on uncertainty category, empirical uncertainty, quality of methods, the longevity of the uncertainty information and the times and locations for which the uncertainty information is valid.

\subsection{Importance of different uncertainty factors}

The most important uncertainty factors of river water quality data are sampling and measurement or analytical uncertainties. Conceptual problems and conversion of data transfer are of minor importance. Sampling uncertainties can be categorised between uncertainties related to the selection of a representative sampling location, representative samples at a given river cross section and the choice of an appropriate sample frequency e.g. for calculation of representative loads at a given location (see Table 2).
The choice of a sampling location may have considerable impact on the measured concentration of a given variable. In streams and small rivers with high flow velocities water quality compounds are in general well mixed within the cross section due to high turbulence of the flow. Temporal and spatial variations of water quality variable concentrations in a given river reach are determined by point sources and the transformation rate of the specific water quality variable. In large rivers the selection of a representative sampling location is much more difficult due to much longer time spans of total mixing of larger tributaries. An example is given for the Chl a concentrations in the Elbe river in Fig. 1. In the case of low flow conditions total mixing of the Saale tributary within the Elbe River needs about $70 \mathrm{~km}$.

The Saale River is the largest German tributary of the Elbe river. Within this river reach considerable differences for most water quality variables can be observed on the right and left bank of the river (see also Guhr et al., 2000). The choice of a representative sampling within a cross section depends on the variability of a given compound, where the variability of suspended particulate matter and associated compounds in general is much larger than of soluble compounds. This variability is highly specific for each river system and river location. Therefore it is not possible to give general quantitative estimates on the uncertainties associated with sampling in a given cross section. It should be apparent that the collection of a single "grab" sample at a single depth, from the centroid of flow or from the bank is unlikely to produce representative samples especially of suspended particulate matter and associated constituents. Some qualitative explanations are given in the following chapters for the different water quality groups. The same is true for the choice of representative sampling frequencies for reliable load calculations.

The methodology used to structure the uncertainty is based on a fourfold distinction between the empirical quality of data, the sources of uncertainty in data, the fitness for use 
Chlorophyll a $(\mu \mathrm{g} / \mathrm{l})$

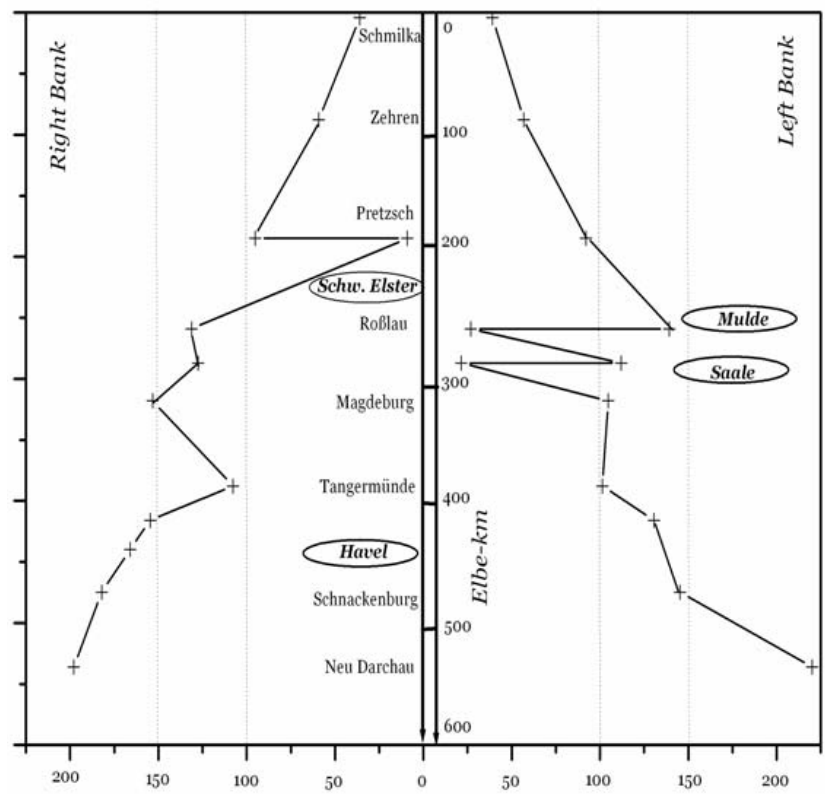

Fig. 1. Chl a longitudinal section of the Elbe sampling survey from Schmilka to Neu Darchau dated 3-11 September 1998.

of data and the goodness of an uncertainty model (van Loon et al., 2006). In this paper we focus on the empirical quality of data and its sources of uncertainty through a literature review and additional monitoring data of the Elbe River. In order to develop probability models for attribute uncertainty, it is useful to distinguish between the space-time variability and the measurement scale. In Table 3 the category B1 indicates variation in time but not in space and a continuous numerical measurement scale. The category D1 specifies variability in time and space and also a continuous numerical measurement scale. For more details see Brown et al. (2005). Also analytical errors can be stated for nearly all variables with an empirical uncertainty M1 which indicates that a probability distribution or upper and lower bounds can be specified. Instrument quality is always adequate for the field situation and calibrated if standard procedures are used (I3, see Table 3). The quality of the sampling strategy can be divided in four classis and water quality variables are determined in most cases based on large samples of direct measurements, good sample design and controlled experiments indicated by S3 in Table 3. The sampling strategy is also specified according to the spatial dimension ( $\mathrm{Sh}=$ horizontal, $\mathrm{Sv}=$ vertical), and also in time $(\mathrm{St})$. The overall method is always approved standard in well established disciplines (O3). Furthermore the description of uncertainty information is known to change over time what is specified by the term "longevity". The code L1 indicates that the uncertainty information is known to change over time and L2 indicates that it does not (see also van Loon et al., 2005). Information on autocorrelation of time series data is rare in the literature.
If possible additional information is given in the following sections. Quantitative estimates on uncertainties for the variable groups like coefficients of variation $(\mathrm{CV})$ of probability distribution functions (pdf) are restricted to measurement and analytical uncertainties due to the lack of information and site specific characteristics of other uncertainty information (see Table 5). The given values on mean standard deviations are general estimates for the analytical methods considered in Table 1. The estimation of uncertainty in sampling can only be done by taking at least a proportion of samples in duplicates. A detailed review of techniques for quantification and comparison of sampling and analytical sources of uncertainties is given e.g. by Ramsey (1998).

\section{Groups of variables}

\subsection{Suspended sediments}

Suspended sediments are defined as the portion of total solids retained by a filter. The currently accepted operational definition of the filter size is a $0.45 \mu \mathrm{m}$ membrane filter (Horowitz, 1997). Bedload is not considered in the following sections and the discussion on river load calculations. Suspended sediments are a major carrier of a variety of mineral and organic constituents. Obtaining representative samples of suspended sediments is, therefore, of fundamental importance in studies concerned with quantifying geochemical fluxes and understanding water quality in fluvial systems. Even in water with suspended sediment concentrations $<10 \mathrm{mg} / \mathrm{l}$, these solids are responsible for the transport of many compounds like trace elements. The collection of representative samples of suspended sediments is of paramount importance, as it is impossible to sample and analyse an entire water body.

The uncertainty category of suspended sediments can be defined as D1, since automatic samplers are able to collect samples with high temporal resolution, e.g. 5 min intervals. In many cases suspended sediments are also sampled on regular daily, weekly or biweekly intervals. Empirical uncertainties encountered with suspended sediments can be defined as type M1 (probability distribution). In general, suspended sediment concentrations have extremely high variations within the cross sectional area of a given river. When both sand-sized $(>63 \mu \mathrm{m})$ and silt/clay-sized $(<63 \mu \mathrm{m})$ particles are present in a stream, the concentrations of suspended sediments tend to increase with increasing distance from the river bank. This is a common pattern and results from an increase in stream velocity (discharge) due to decreasing frictional resistance from the river banks and the river bed (Vanoni, 1977). Vertical concentrations of fluvial suspended sediments tend to increase with increasing depth. This is also due to the increase of sand sized material. This occurs because the velocity (discharge) in most rivers, under normal flow conditions, is insufficient to distribute coarse material homogeneously. Hence the majority of sand sized 
Table 3. Example table, giving information about Uncertainty category, type of empirical uncertainty, methodological quality and longevity.

\begin{tabular}{|c|c|c|c|c|c|c|}
\hline \multirow{2}{*}{$\begin{array}{l}\text { Variable } \\
\text { Abbreviation }\end{array}$} & \multirow{2}{*}{$\begin{array}{l}\text { Uncertainty } \\
\text { category }\end{array}$} & \multirow{2}{*}{$\begin{array}{l}\text { Empirical } \\
\text { uncertainty }\end{array}$} & \multicolumn{4}{|c|}{ Methodological quality } \\
\hline & & & Instr. & Samp. & Overall & Longevity \\
\hline Sed & D1 & M1 & I3 & Sh3, Sv3, St3 & $\mathrm{O} 3$ & L1 \\
\hline $\mathrm{NO}_{3}$-EM, $\mathrm{NO}_{3}$-CRM & B1, B1 & M1 & I3 & $\mathrm{St} 3$ & $\mathrm{O} 3$ & L2 \\
\hline $\mathrm{NO}_{2}$ & B1 & M1 & I3 & $\mathrm{St} 3$ & $\mathrm{O} 3$ & $\mathrm{~L} 2$ \\
\hline $\mathrm{NH}_{4}$ & B1 & M1 & $\mathrm{I} 3$ & St3 & $\mathrm{O} 3$ & L2 \\
\hline $\mathrm{TP}$ & D1 & M1 & I3 & Sh3, Sv3, St3 & $\mathrm{O} 3$ & $\mathrm{~L} 2$ \\
\hline PP & D1 & M1 & I3 & $\mathrm{Sh} 3, \mathrm{~Sv} 3, \mathrm{St} 3$ & $\mathrm{O} 3$ & $\mathrm{~L} 2$ \\
\hline DP & B1 & M1 & I3 & St3 & $\mathrm{O} 3$ & $\mathrm{~L} 2$ \\
\hline SRP & B1 & M1 & I3 & $\mathrm{St} 3$ & $\mathrm{O} 3$ & L2 \\
\hline COD & B1 & M1 & I3 & St3 & $\mathrm{O} 3$ & L2 \\
\hline BOD & B1 & M1 & I3 & $\mathrm{St} 3$ & $\mathrm{O} 3$ & $\mathrm{~L} 2$ \\
\hline Chl-a & D1 & M1 & I3 & Sh2, Sv2, St2* & $\mathrm{O} 3$ & $\mathrm{~L} 2$ \\
\hline DOC & B1 & M1 & I3 & $\mathrm{St} 3$ & $\mathrm{O} 3$ & L2 \\
\hline $\mathrm{As}, \mathrm{Cr}, \mathrm{Cu}, \mathrm{Fe}, \mathrm{Hg}, \mathrm{Mn}, \mathrm{Pb}, \mathrm{Zn}$ & D1 & M1 & I3 & Sh3,Sv3,St3 & $\mathrm{O} 3$ & L2 \\
\hline
\end{tabular}

* in the case of algal biomass determination

particles tend to be transported near the river bed. Therefore it should be apparent that collection of a grab sample at a single depth, from the centroid of flow or from one bank is unlikely to produce representative samples of suspended sediments (Horowitz, 1997; Horowitz et al., 1989).

Representative suspended sediment sampling requires a composite of a series of depth- and width-integrated isokinetic samples obtained either at equal discharge or at equal width increments across a river (Horowitz et al., 1990; Horowitz, 1997). The increased velocities and turbulence found in the centre of many rivers leads to lateral variation of suspended sediment concentrations with elevated values in the middle of the cross section. Most of this variation in suspended sediment concentration in a section is accounted for by the sand fraction $(>63 \mu \mathrm{m})$, hence the variations in the case of sediment concentrations dominated by silt and clay fraction, e.g. under low flow conditions, is less important. Investigations into vertical variations in sediment concentrations conducted by Wass and Leeks (1999) revealed well mixed conditions for English rivers. These rivers varied in catchment size between 484 and $8231 \mathrm{~km}^{2}$ and mean suspended sediment concentrations less than $60 \mathrm{mg}^{-1}$ and maximum suspended sediment concentrations less than $1600 \mathrm{mg}^{-1}$. The errors of single samples within a cross section compared with measurements made using depthintegrated samplers across a section leaded to errors ranging from 2 to $12 \%$ (Wass and Leeks, 1999).

It is well known that suspended sediments concentrations also have high temporal variations. Although a number of factors other than just discharge are involved (e.g. grainsize distribution, shear stress, turbulence, stream-bed gradient), there is a widely held belief that in fluvial systems, as discharge increases, suspended concentrations also increases (Horowitz, 1997). Commonly about $90 \%$ of the an- nual load is transported within only about $10 \%$ of the time (e.g. Walling et al., 1992; Horowitz, 1995). Sampling frequency for flux estimates becomes dependent on the time period of concern (daily, weekly, monthly, yearly) and the amount of acceptable error associated with these estimates.

Sample volume should be chosen to yield between 2.5 and $200 \mathrm{mg}$ dried residue. Commonly samples are dried by 103 to $105^{\circ} \mathrm{C}$ in an oven, cooled in a desiccator to balance the temperature, and weighed. The standard deviation was $5.2 \mathrm{mg} / \mathrm{L}$ (coefficient of variation $33 \%$ ) at $15 \mathrm{mg} / \mathrm{L}, 24 \mathrm{mg} / \mathrm{L}$ $(10 \%)$ at $242 \mathrm{mg} / \mathrm{L}$, and $13 \mathrm{mg} / \mathrm{L}(0.76 \%)$ at $1707 \mathrm{mg} / \mathrm{L}$ in studies by two analysts of four sets of 10 determinations each. Single-laboratory duplicate analyses of 50 samples of water and wastewater were made with a standard deviation of differences of $2.8 \mathrm{mg} / \mathrm{L}$ (Standard Methods, 1998). This indicates that the absolute analytical measurement error is nearly constant and the percentage measurement error decreases with increasing suspended sediment concentrations. For suspended sediment concentrations problems related to collecting representative samples (one that encompass the range of spatial and temporal variability at a site) are of primary concern compared to analytic uncertainties.

\section{$2.2 \mathrm{~N}$-fraction}

In surface waters the forms of nitrogen of greatest interest are, in order of decreasing oxidation state, nitrate, nitrite, ammonia and organic nitrogen. All these forms of nitrogen are biochemically interconvertible and are components of the nitrogen cycle. Regarding nitrate the automated cadmium reduction method $\left(\mathrm{NO}_{3}-\mathrm{CRM}\right)$ is a commonly used method for nitrate analytical determination. Nitrate can be determined over a range of 0.5 to $10 \mathrm{mg}$ N/l. Sample turbidity may interfere with the analytical procedure. Table 4 
Table 4. $\mathrm{NO}_{3}^{-}-\mathrm{N}$ concentrations, standard deviations and bias for different nitrate concentrations increments obtained in three different laboratories (Standard Methods, 1998).

\begin{tabular}{rrrr}
\hline $\begin{array}{r}\text { Increment as } \\
\mathrm{NO}_{3}^{-}-\mathrm{N} \\
\mu \mathrm{g} / \mathrm{L}\end{array}$ & $\begin{array}{r}\text { Standard } \\
\text { Deviation } \\
\mu \mathrm{gN} / \mathrm{L}\end{array}$ & $\begin{array}{r}\text { Bias } \\
\%\end{array}$ & $\begin{array}{r}\text { Bias } \\
\mu \mathrm{gN} / \mathrm{L}\end{array}$ \\
\hline 290 & 12 & +5.75 & +17 \\
350 & 92 & +18.10 & +63 \\
2310 & 318 & +4.47 & +103 \\
2480 & 176 & -2.69 & -67 \\
\hline
\end{tabular}

shows an example of systematic error (bias) based on the analysis of four natural water samples containing exact increments of inorganic nitrate. The analyses were carried out by three laboratories using the same automated systems but having slightly different configurations.

In a single laboratory using surface water samples at concentrations of $100,200,800$, and $2100 \mu \mathrm{gN} / \mathrm{L}$, the standard deviation were $0, \pm 40, \pm 50$, and $\pm 50 \mu \mathrm{gN} / \mathrm{L}$, respectively. These findings for nitrate on decreasing relative precision (random error) with increasing concentrations are typical also for other water quality constituents and most analytical methods. Precision and bias for the system described are believed to be comparable (Standard Methods, 1998). The standard deviations reported from the Laboratory of the Helmholtz Centre for Environmental Research - UFZ in Magdeburg are with a maximum of 3.3\% similar to these findings. The analytical limit is about $50 \mu \mathrm{gN} / \mathrm{L}$. The $\mathrm{NO}_{3}-$ Electrode Method (EM) has detection limits between 0.14 and $1400 \mathrm{mg} \mathrm{NO}-\mathrm{N} / \mathrm{L}$ and $\mathrm{pH}$-values have to be held constant. Over the range of the method, precision of $\pm 0.4 \mathrm{mV}$, corresponding to $2.5 \%$ in concentration, is expected (Standard Methods, 1998). Nitrite is an intermediate oxidation state of nitrogen, both in the oxidation of ammonia to nitrate and in the reduction of nitrate. Mean standard deviations change slightly depending on the analytical method. Colorimetric methods may have somewhat lower precision than the Ion Chromatography (IC) method. In general measurement errors should be not higher than $6 \%$. The relative precision will increase with increasing concentrations.

Ammonia is present naturally in surface and wastewaters. Its concentration is generally low in groundwater because it adsorbs to soil particles and clays and is not leached from the soils. Ammonia concentration can vary between $10 \mu \mathrm{g} / \mathrm{l}$ ammonia nitrogen in some natural groundwater systems and $30 \mathrm{mg} / \mathrm{L}$ in some wastewater. Ammonia concentrations in surface water, e.g. due to wastewater inputs, tend to decrease rapidly by nitrification. Mean standard deviation of analytical methods have values between 5 and $8 \%$ where the IC method showed highest standard deviation of up to $11 \%$ (DEV, 2000). The lowest bias is associated with the

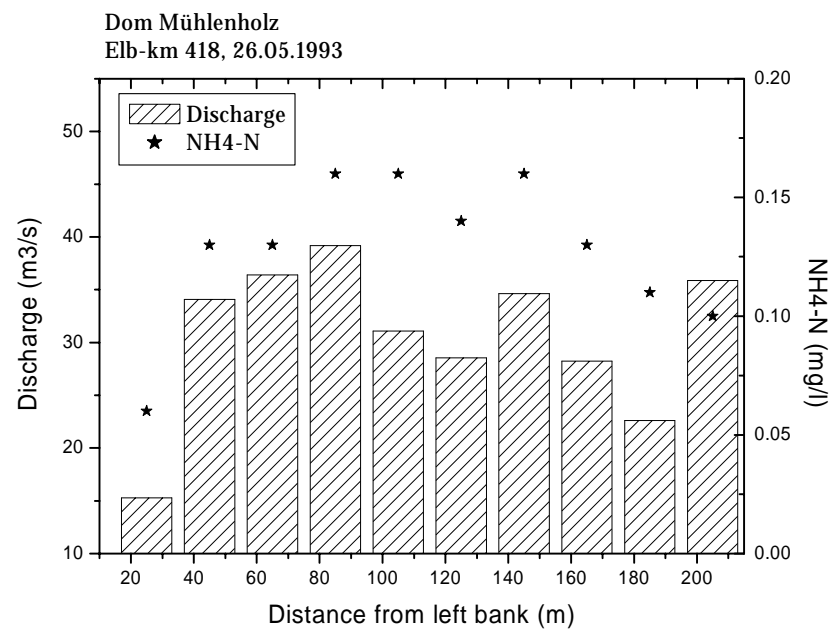

Fig. 2. $\mathrm{NH}_{4}-\mathrm{N}$ concentrations and discharge within different segments of the cross section in the Elbe River at location Dom Mühlenholz on 26 May 1993.

flow injection analysis (Standard Methods, 1998). In general, soluble compounds like ammonia have much lower concentration variation within a cross section of a given stream or river compared to suspended sediment associated compounds. Nevertheless during low flow season and high biological activity also soluble concentrations of reactive compounds may vary considerably. Figure 2 shows deviations of ammonia concentrations within the cross-section of the Elbe River of more than $50 \%$ of the mean value. This is due to high algal biomass concentration and associated nutrient uptake or higher nitrification rates in the proximity of the banks, which are modified by groynes. These effects may be much more important for larger rivers than for small rivers and streams due to their higher turbulence and mixing within the cross section.

Studies on autocorrelation in nitrogen time series mainly focus on trend analysis and the determination of seasonal trend components (Lehmann and Rode, 2001; Worrall and Burt, 1999). Published studies on simple temporal autocorrelation of nitrogen time series are rare and are restricted to weekly nitrate data. No studies were found on the systematic analyses of temporal autocorrelation functions on time series data. Markus et al. (2003) showed high autocorrelation of lag-one nitrate- $\mathrm{N}$ for the Sangamon River in the Midwestern United States. Two week temporal autocorrelation was lower but still higher than 0.6. During high nitrate concentrations seasonal autocorrelations seemed to be higher than during low concentrations (Markus et al., 2003). Correlation between nitrogen compounds and other water quality constituents are frequent and depend on site specific nitrogen loadings e.g. the share of point and non point sources pollution. In general the correlation between discharge and nitrate is weak due to the highly nonlinear relationship between discharge and nitrate concentration. 
Table 5. Information about error probability distribution type, analytical uncertainties and data support (see also Table 8.1 for meaning of variables).

\begin{tabular}{|c|c|c|c|c|c|}
\hline $\begin{array}{l}\text { Variable } \\
\text { Abbrev. }\end{array}$ & pdf type & $\begin{array}{l}\text { pdf } * \\
\text { CV }\end{array}$ & Volume & $\begin{array}{l}\text { Ipport } \\
\text { Sampling Time }\end{array}$ & References \\
\hline Sed & lognormal & $13 \%$ & $1-51$ & seconds & $\begin{array}{l}\text { WMO (1989); DEV, 35th } \\
\text { Delivery (1996); Ferguson } \\
\text { (1986) }\end{array}$ \\
\hline $\mathrm{NO}_{3}-\mathrm{CRM}$ & normal & $5 \%$ & $100 \mathrm{ml}$ & $\mathrm{s}$ & Standard Methods (1998) \\
\hline $\mathrm{NO}_{3}$-EM & normal & $2.5 \%$ & $10 \mathrm{ml}$ & $\mathrm{s}$ & Standard Methods (1998) \\
\hline $\mathrm{NO}_{3}-\mathrm{IC}$ & normal & $4 \%$ & $100 \mathrm{ml}$ & $\mathrm{s}$ & Standard Methods (1998) \\
\hline $\mathrm{NO}_{2}$ & normal & $6 \%$ & $100 \mathrm{ml}$ & $\mathrm{s}$ & $\begin{array}{l}\text { Standard Methods (1998); } \\
\text { DEV, 38th Delivery (1997) }\end{array}$ \\
\hline $\mathrm{NH}_{4}$ & normal & $11 \%$ & $100 \mathrm{ml}$ & $\mathrm{s}$ & DEV, 48th Delivery (2000) \\
\hline $\mathrm{TP}$ & normal & $6 \%$ & $100 \mathrm{ml}$ & $\mathrm{s}$ & According to SRP \\
\hline SRP & normal & $6 \%$ & $100 \mathrm{ml}$ & $\mathrm{s}$ & $\begin{array}{l}\text { Standard Methods (1998); } \\
\text { DEV, 38th Delivery (1997) }\end{array}$ \\
\hline COD & normal & $11 \%$ & $500 \mathrm{ml}$ & $\mathrm{s}$ & $\begin{array}{l}\text { Standard Methods (1998); } \\
\text { DEV, 9th Delivery (1981) }\end{array}$ \\
\hline BOD & normal & $10 \%$ & $300 \mathrm{ml}$ & s & $\begin{array}{l}\text { Standard Methods (1998); } \\
\text { DEV, 43th Delivery (1999) }\end{array}$ \\
\hline Chl-a & normal & $10 \%$ & $2 \mathrm{~mL} / \mathrm{min}$ & $\mathrm{s}$ & Standard Methods (1998) \\
\hline DOC & normal & $10 \%$ & & $\mathrm{~s}$ & Standard Methods (1998) \\
\hline $\mathrm{As}, \mathrm{Cr}, \mathrm{Cu}, \mathrm{Fe}, \mathrm{Mn}, \mathrm{Pb}, \mathrm{Zn}$ & normal & $5 \%$ & $100 \mathrm{ml}$ & $\mathrm{s}$ & Standard Methods (1998) \\
\hline $\mathrm{Hg}$ & normal & $10-17 \%$ & $100 \mathrm{ml}$ & s & Standard Methods (1998) \\
\hline
\end{tabular}

* restricted to analytical errors

\section{$2.3 \mathrm{P}$ fraction}

Phosphorus occurs in natural waters and in wastewaters almost solely as phosphates. They occur in solution, in particles or detritus, or in the bodies of aquatic organisms. Phosphorus is essential to the growth of organisms and can be the nutrient that limits the primary productivity of a water body. Phosphorus analyses embody two general procedural steps: (a) conversion of the phosphorus form of interest like soluble reactive phosphorus, dissolved phosphorus or total phosphorus to dissolved orthophosphate, and b) determination of dissolved orthophosphate by ion chromatography (IC) or colorimetry. In Table 5 standard deviations of the IC method and additional uncertainty information are given for soluble reactive phosphorus (SRP).

The values for the colorimetric determinations are comparable. In determination of total dissolved or total suspended reactive phosphorus, anomalous results may be obtained on samples containing large amounts of suspended sediments. Very often results depend largely on the degree of agitation and mixing to which samples are subjected during analysis because of a time-dependent desorption of orthophosphate from the suspended particles (Standard Methods, 1998). Due to strong binding of phosphorus to suspended particulate matter concentrations of P-compounds vary within the cross sectional area depending on the amount of suspended sediments or organic matter (e.g. algal biomass) in the water body.
Furthermore, dissolved concentrations of P-compounds may vary within the cross section due to differing algal $\mathrm{P}$ uptake (see Fig. 3). In rivers with low algal biomass concentrations or well mixed water bodies the cross sectional variation may not be very important. Suspended sediment concentrations (see above) as well as biological activities vary strongly in space and time. Therefore, autocorrelation of $\mathrm{P}$ concentrations may be much lower than for variables which are less impacted by biological transformation or transport by suspended sediments like e.g. nitrate. The investigations of Tonderski et al. (1995) from the Vistula River supported these findings. They found that day-to-day variations of cross section mean values was sometimes smaller than cross section variation for sediment associated variables like total phosphorus.

\subsection{Heavy metals}

Suspended sediment associated heavy metals can display marked short- and long term spatial and temporal variability. Transport of heavy metals occurs mainly in association with suspended sediments. Even in waters with suspended sediment concentrations $<10 \mathrm{mg} / \mathrm{l}$, these solids can represent the major carrier for many trace elements (Horowitz, 1997). Therefore, the behaviour of trace elements is very similar to the behaviour of suspended sediments. Although concentrations of suspended associated compounds can vary strongly within the cross sectional area during high flow and sediment 


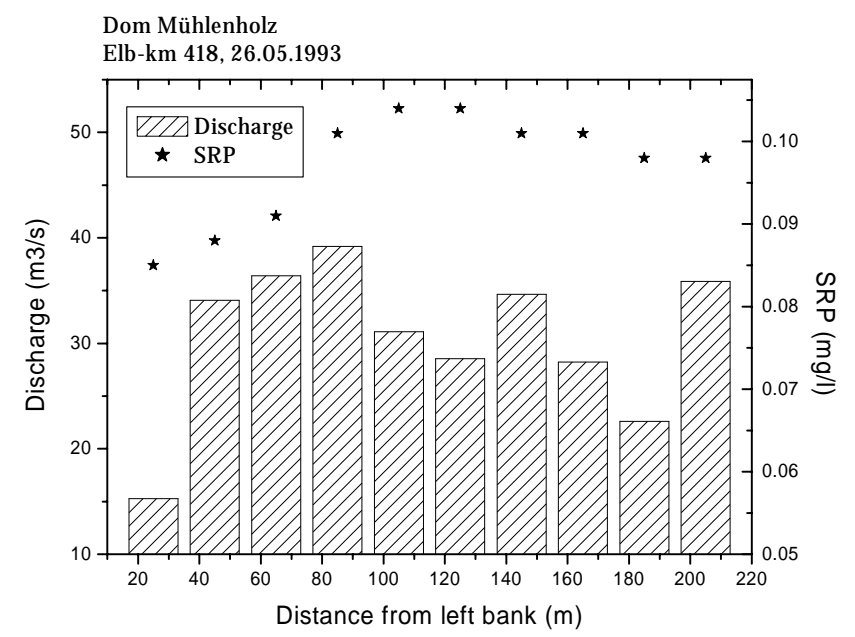

Fig. 3. Mean SRP-concentrations within the cross section in the Elbe River at location Dom Mühlenholz on 26 May 1993.

concentration conditions (Horowitz, 1997), this variation decrease rapidly during low flow conditions with associated low suspended sediment concentrations. For the Elbe River Cd concentration did not vary systematically within the cross section with high concentrations in the centre of the cross section and low concentrations near the banks (see Fig. 4). These findings are restricted to low suspended sediment concentrations since in all 14 cross section measurement surveys in 1993 and 1994 in the Elbe River these concentrations were always less than $40 \mathrm{mg} / \mathrm{l}$. As discharge increases it is commonly assumed that the grain size composition of suspended sediment will show a decrease in the clay fraction and an increase in the sand fraction, because of the increase in turbulence and transport capacity for coarser particles associated with higher flows (Horowitz, 1997). Due to the association of heavy metals with more chemically active fine fraction this will in general lead to a decrease of relative sediment associated trace element concentration with increase discharge (Walling et al., 1992). However, it should not be assumed that all rivers will demonstrate this typical grain size behaviour. Walling et al. (1992) showed that rivers often have their very specific transport characteristics and pattern of variation of the concentration of sediment associated substances. In assessing the uncertainties of heavy metal concentration data this leads to the general statement that most monitoring programs lack the necessary resources to sample with sufficient frequency to encompass the degree of temporal variability typical in most fluvial systems. Hence sampling uncertainty, especially for sediment related compounds, is much more important than measurement uncertainty, where high precise and unbiased analytical results are achievable with ICP-based instrumentations. These measurement uncertainties are presented in Table 5. It is questionable whether this analytical effort is justified due to only a limited number of suspended sediment samples.

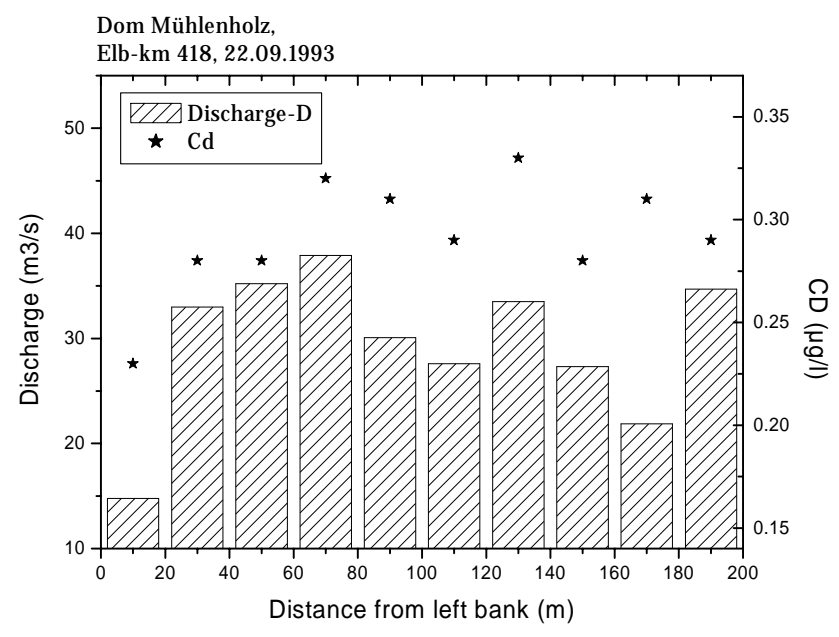

Fig. 4. Mean Cd-concentrations within the cross section in the Elbe River at location Hohenwarte on 21 October 1993.

\subsection{Biological fractions}

The biological fraction comprises compounds that are mainly impacted by the amount of, the generation or the degradation of organic matter in surface water. Organic matter originates from allochtonous (e.g. waste water) or autochtonous sources (primary production). The biochemical oxygen demand (BOD) is a measure for the molecular oxygen utilized during a specific incubation period for the biochemical degradation of organic material and the oxygen used to oxidize inorganic material such as sulphides and ferrous iron. Chemical oxygen demand (COD) is defined as the amount of a specific oxidant that reacts with the sample under controlled conditions. COD is often closely related to BOD. Uncertainties associated with different measurement methods for BOD and COD seemed to be comparable and are given in Table 5. They are slightly higher than analytical uncertainties of most nutrients. Analytical uncertainties will decrease with increasing concentrations of DOC and BOD. For further literature see e.g. Standard Methods (1998).

The concentration of photosynthetic pigments like chlorophyll a is used extensively to estimate phytoplankton biomass where the High-Performed Liquid Chromatography (HPLC) method is the most commonly used method. Uncertainties of the HPLC method varies between the different pigment types and can vary between 0.5 and $23 \%$ with an average value of $10 \%$ for seven investigated pigment types (Standard Methods, 1998). Uncertainties compared with other methods like spectrometric or fluorometric methods are similar. These uncertainties are restricted to the quantification of pigments and do not reflect the uncertainties associated with these indirect methods to determine phytoplankton biomass. Compared to direct measurement of phytoplankton the indirect measurement with pigment concentration is associated with additional uncertainties since the relationship between both 
variables is not constant. This relationship strongly depends on the composition of different algal groups and on the cell size of the algae (Creitz and Richards, 1955). Figure 5 shows an example relationship between $\mathrm{Chl}$ a and algal biomass. The correlation between biovolume and extracted chlorophyll is not always reliable and this has been widely discussed (Desortova, 1981; Vörös and Padisak, 1991). Therefore pigment concentration is a rough estimator of total algal biomass. In large rivers algal concentrations may differ within the river cross section with slightly higher concentrations near the river banks compared to the centre of the river. This is due to larger flow depth in the centre of the cross section. Assuming total mixing of the water column and high algal concentrations the penetration of light is limited.

Regarding the predictability of algal concentrations Hakanson et al. (2003) discussed fundamental principles regulating predictive power of river models for phytoplankton. Their general idea is that the variation of phytoplankton concentrations expressed as $\mathrm{CV}$ values determine their overall uncertainty and hence their predictability. They analysed extensive data of different phytoplankton groups on a site in the Danube River and in 19 rivers in the UK. The CV-value for within site variability is always related to very complex climatological, biological, chemical and physical conditions. In the Danube river case study $\mathrm{CV}$ values were similar for the different phytoplankton groups but there was a temporal variation in monthly $\mathrm{CV}$ s based on data from several years with highest $\mathrm{CV}$ during September and October. The mean CV for chlorophyll based on all data from the River Danube is 0.96 , which is close to the median value from 19 river sites in the UK. It has been shown that it is often possible to define a characteristic $\mathrm{CV}$-value for a given variable, e.g. chl a values in lakes, and that they can give information on the general predictability of a given variable (Hakanson, 1999).

\section{River load calculations and uncertainties}

One of the greatest problems associated with the provision of reliable river load data is the assumption that the infrequent samples typically associated with routine water quality monitoring programmes can be used to generate reliable estimates of river loads. In most situations, the accurate assessment of river loads will require a sampling programme specifically designed for this purpose. Additionally when observed concentrations are serially dependent the calculation of the uncertainty of transport estimates can be supported by the use of autoregressive-moving average models for time series of concentration data (Tonderski et al., 1995). In considering further the problems of obtaining accurate estimates of river loads, it is useful to make a distinction between the dissolved and the particulate components of river load (Walling et al., 1992). In many situations, the concentrations of most dissolved substances in river water will vary over a limited range and the use of infrequent samples may

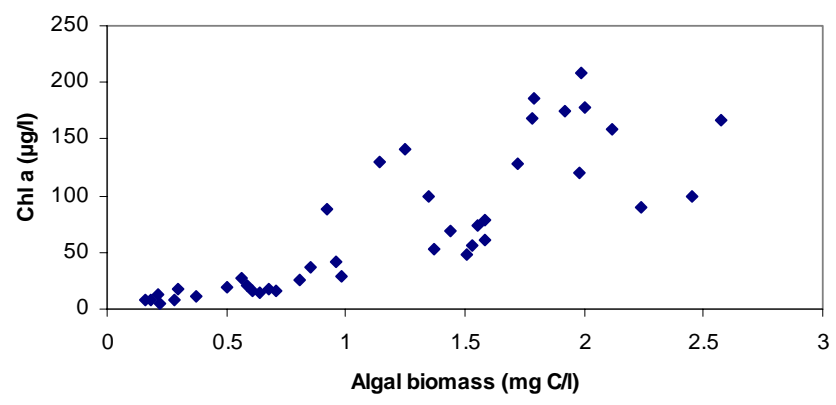

Fig. 5. Relationship between $\mathrm{Chl}$ a concentrations and algal biomass of water samples from the river Elbe in 1997.

introduce only relatively limited errors into load assessments, if accurate information on water discharge is available. In the case of particulate- or sediment associated compounds, however, concentrations may vary over several orders of magnitude, particularly during flood events.

Over the last two decades a wide variety of estimation approaches have been developed and used for the estimation of loads of various water quality constituents. These approaches can be divided into averaging, ratio and regression estimators. A short overview is given by Preston et al. (1989) and Cohn (1995). Whereas the two former estimators were used for all water constituents, regression methods have traditionally been applied for estimating tributary loads of suspended solids and other related constituents. Guo et al. (2002) demonstrated that in the case of nitrate, which is representative for dissolved compounds, all methods produced relatively small errors (up to $5 \%$ ) for yearly load calculations in a case study of the Sagamon River in Illinois, USA. The catchment sizes were up to $2375 \mathrm{~km}^{2}$ with nitrate concentrations of up to $10 \mathrm{mg} / \mathrm{l}$ nitrate- $\mathrm{N}$. These results were achieved on the basis of weekly and monthly sampling frequencies. In all cases simple averaging and ratio estimators yielded better results than the rating curve method. These results can be supported by the findings of Littlewood (1995) who used averaging estimators for nitrate-N load calculation using a $578 \mathrm{~km}^{2}$ British Stour at Langham catchment as a case study. Deviations between calculated loads on the basis of a 20 day sampling interval and the actual load were about $5 \%$. In general in river catchments of comparable size biweekly sample frequencies, which are most common for European monitoring programs will lead to reasonable yearly dissolved load calculations.

For suspended sediment flux calculations generally loglog regressions are applied because flow and concentration are assumed to follow a bivariate lognormal distribution. Ferguson (1986) and Koch and Smillie (1986) demonstrated that the log-log regression procedure is theoretically biased because of the retransformation from the log scale to the linear scale. Therefore, sediment rating curves can substantially underpredict actual concentrations and loads (see also Asselmann, 2000) and various correction factors have been 
developed to compensate this difficulty (e.g. Ferguson, 1986; Walling and Webb, 1988; Asselmann, 2000). Using the rating curve technique Horowitz (2003) investigated the impact of sampling frequency on the annual flux estimates for large rivers. For the investigated Mississippi River and Rhine River even collecting a sample as infrequently as once a mouth produced differences only of the order of less than $\pm 20 \%$, regardless of the flux levels compared to true load calculations based on daily samples. The analysis of nutrient concentrations and flow data from four major European rivers showed that for load calculations i) linear interpolation between adjacent concentrations values was not inferior to other, more complex interpolation methods and ii) the interpolation errors in the time series of concentrations were not correlated to the water flow. This absence of correlation justifies the use of load estimators based on linear interpolation of observed concentrations (Tonderski et al., 1995). These findings were confirmed by Moatar and Meybeck (2005) who tested several flux estimation procedures at the Loire River for nitrogen and phosphorus constituents. The frequency of water quality surveys required to obtain an annual nutrient flux with $10 \%$ precision was around 15 days for nitrate, 10 days for SRP and total P, and about 5 days in the case of particulate P. Moatar and Meybeck (2006) could demonstrate in a comparative river study, that the suspended sediment transport regime of rivers effects the accuracy and precision of flux estimates for given sampling frequencies. They introduced descriptors of the suspended sediment flux regime which can be related to both accuracy and precision. Compared to large rivers the uncertainties associated with load estimates based on infrequent samples will increase for small basins. Furthermore in small rivers, where single events play a relatively more important role, the problem of calculating transports is of a different character (Rekolainen et al., 1991; Reinelt and Grimvall, 1991).

An assessment of the likely reliability of suspended sediment loads estimated on the basis of infrequent samples using $1500 \mathrm{~km}^{2}$ basin of the River Exe indicated that errors of the order of $\pm 75 \%$ or even greater could arise (see also Walling and Webb, 1981). Errors associated with variability of the concentrations of sediment associated substances are likely to be less (Walling et al., 1992). A comparative study on load estimation methodologies using the River Wharfe at Tadcaster form Webb et al. (1997) showed that simple rating relationships produced estimates of suspended sediment load with the highest level of accuracy, but loads calculated by this procedure still varied from $-57 \%$ to $+29 \%$ of the true value using weekly sampling interval. None of the methods investigated produced very reliable load estimates when weekly suspended sediment concentrations data were used. To reduce uncertainties in river water quality data especially with respect to matter flux calculations sampling strategies have been developed stressing high temporal variations and the importance of sampling at times of high discharge (Robertson and Roerisch, 1999). Monte Carlo simulations can be used to establish optimized sampling strategies and load estimation techniques.

\section{Conclusions}

This chapter on uncertainties of river water quality data deals with five different groups of variables listed in Table 1, i.e. suspended sediment, nitrogen fraction, phosphorus fraction, heavy metals and biological compounds. All data of compounds associated with suspended particulate matter have considerable higher sampling uncertainties than soluble concentrations. This is due to high variability's within the cross section of a given river reach. This variability is positively correlated with total suspended particulate matter concentrations. Sampling location has also considerable effect on the representativeness of a water sample. This is especially true for larger rivers with large tributaries and low flow velocities. High sampling effort is needed to get representative samples of a given cross section. These sampling uncertainties are highly site specific. Spatial variation of concentrations within a given river cross section can make a substantial contribution to the uncertainty of transport estimates. The estimation of uncertainty in sampling can only be achieved by taking at least a proportion of samples in duplicates. A detailed review of techniques for quantification and comparison of sampling and analytical sources of uncertainties is given e.g. by Ramsey (1998). Compared to sampling uncertainties measurement and analytical uncertainties are much lower. Instrument quality is adequate for field and laboratory situations for all considered constituents and most variables can be analysed by direct measurements. All analytical methods have approved standards in well established disciplines. Nevertheless analytical errors can contribute considerable to the overall uncertainty of river water quality data. In most cases variation of analytical errors between different well approved analytical methods are small. There is a welldeveloped literature on assessing systematic and random errors on the analysis of trends (e.g. Gilbert, 1987; Alexander et al., 1993; McBride and Smith, 1997). A recent work of Moosmann et al. (2005) described how to determine the number of annual samples required to detect trends in nutrient load, depending on monitoring duration, available resources, and the magnitude of the expected trend.

Acknowledgements. We thank H. Guhr from the Department of River Ecology, Helmholtz Centre for Environmental Research UFZ, Germany, for valuable comments on the manuscript. The Department of River Ecology, UFZ, kindly provided data of the Elbe River used in this study. The present work was carried out within the Project "Harmonised Techniques and Representative River Basin Data for Assessment and Use of Uncertainty Information in Integrated Water Management (HarmoniRiB)", which is partly funded by the EC Energy, Environment and Sustainable Development programme (Contract EVK1-CT2002-00109).

Edited by: E. van Loon 


\section{References}

Alexander, R. B., Smith, R. A., and Schwarz, G. E.: Correction of stream quality trends for the effects of laboratory measurements bias, Water Resources Research, 29(11) 3821-3833, 1993.

Arheimer, B. and Olsson, J.: Integration and coupling of hydrological models with water quality models, Applications in Europe, Report of the Swedish Meteorological and Hydrological Institute, Norrköping Sweden, p. 49, 2003.

Asselmann, N. E. M.: Fitting and interpretation of sediment rating curve, J. Hydrol., 234, 228-248, 2000.

Brown, J. D., Heuvelink, G. B. M., and Refsgaard, J. C.: An integrated framework for assessing and recording uncertainties about environmental data, Water Sci. Technol., 52(6), 153-160, 2005.

Creitz, G. I. and Richards, F. A.: The estimation and characterisation of phytoplankton population by pigment analysis, J. Mar. Res., 14, 211-216, 1955.

Cohn, T. A.: Recent advances in statistical methods for the estimation of sediment and nutrient transport in rivers, Rev. Geophys., 1117-1123, 1955.

Deutsches Einheitsverfahren (DEV): Selected methods of water analysis, 9th Delivery, Wiley-VCH, Verlag $\mathrm{GmbH}$ and Co. KGaA, Weinheim, 1981.

Deutsches Einheitsverfahren (DEV): Selected methods of water analysis, 35th Delivery, Wiley-VCH, Verlag $\mathrm{GmbH}$ and Co. KGaA, Weinheim, 1996.

Deutsches Einheitsverfahren (DEV): Selected methods of water analysis, 38th Delivery, Wiley-VCH, Verlag $\mathrm{GmbH}$ and Co. KGaA, Weinheim, 1997.

Deutsches Einheitsverfahren (DEV): Selected methods of water analysis, 43th Delivery, Wiley-VCH, Verlag $\mathrm{GmbH}$ and Co. KGaA, Weinheim, 1999.

Deutsches Einheitsverfahren (DEV): Selected methods of water analysis, 48th Delivery, Wiley-VCH, Verlag $\mathrm{GmbH}$ and Co. KGaA, Weinheim, 2000.

Desertova, B.: Relationship between chlorophyll-a concentration and phytoplankton biomass in several reservoirs in Czechoslovakia, Int. Revues. Hydrobiol., 66(2), 153-169, 1981.

Ferguson, R. I.: River loads underestimation by rating curves, Water Resources Research, 22(1), 74-76, 1986.

Gilbert, R. O.: Statistical Methods for Environmental Pollution Monitoring, Van Nostrand Reinhold Company, 1987.

Guo, Y., Markus, M., and Demissie, M.: Uncertainty of nitrate-n load computations for agricultural watersheds, Water Resources Research, 38(10), 1185-1197, 2002.

Guhr, H., Karrasch, B., and Spott, D.: Shifts in the processes of oxygen and nutrient balances in the river Elbe since the transformation of the economic structure, Acta hydrochim. hydrobiol., 28 (3), 1-7, 2000.

Hakanson, L.: On the principles and factors determining the predictive success of ecosystem models, with a focus on lake eutrophication models, Ecological Modelling, 121, 139-160, 1999.

Hakanson, L., Malmaeus, J. M., Bodemer, U., and Gerhardt, V.: Coefficients of variation for chlorophyll, green algae, diatoms, cryptophytes and blue-greens in rivers as a basis for predictive modelling and aquatic management, Ecological Modelling, 169, 179-196, 2003.

Harmel, R. D., Cooper, R. J., Slade, R. M., Haney, R. L., and Arnold, J. G.: Cumulative uncertainty in measured streamflow and water quality data for small watersheds, Transaction of the
ASABE, 49(3), 689-701, 2006a.

Harmel, R. D., King, K. W., Haggard, B. E., Wren, D. G., and Sheridan J. M.: Practical guidance for discharge and water quality data collection on small watersheds, Transaction of the ASABE, 49(4), 937-948, $2006 \mathrm{~b}$.

Horowitz, A. J.: The use of suspended sediment and associated trace elements in water quality studies, IAHS Special Publication No. 4, IAHS Press, Wallingford, UK, 58 pp., 1995.

Horowitz, A. J.: Some thoughts on problems associated with various sampling media used for environmental monitoring, Analyst, 122, 1193-1200, 1997.

Horowitz, A. J.: An evaluation of sediment rating curves for estimating suspended sediment concentrations for subsequent flux calculations, Hydrological Processes, 17, 3387-3409, 2003.

Horowitz, A. J., Elrick, K. A., and Hooper, R. P.: The prediction of aquatic sediment-associated trace element concentrations using selected geochemical factors, Hydrological Processes, 3, 347364, 1989.

Horowitz, A. J., Rinella, F. A., Lamothe, P., Miller, T. L., Edwards, T. K., Roche, R. L., and Rickert, D. A.: Variation in suspended sediment and associated trace element concentrations in selected riverine cross sections, Environ. Sci. Technol., 24, 1313-1320, 1990.

James, A. (Ed.): An introduction to water quality modelling, John Wiley, Chichester, 1993.

Koch, R. W. and Smillie, G. M.: Bias in hydrologic prediction using log-transformed regression models, Water Resources Bull., 22(5), 717-723, 1986.

Lehmann, A. and Rode, M.: Long-term behaviour and crosscorrelations analysis of water quality parameters of the Elbe river at Magdeburg, Germany, Water Research, 35, 2153-2160, 2001.

Littlewood, I. G.: Hydrological regimes, sampling strategies, and assessment of errors in mass load estimates for United Kingdom rivers, Environmental International, 21(2), 211-220, 1995.

Markus, M., Tsai, C. W.-S., and Demissie, M.: Uncertainty of weekly nitrate-nitrogen forecasts using artificial neural networks, Journal of Environmental Engineering, 129(3), 267-274, 2003.

McBride, G. B. and Smith, D. G.: Sampling and analytical tolerance requirements for detecting trends in water quality, J. of the American Water Resources Association, 33(2), 367-373, 1997.

Moatar, F. and Meybeck, M.: Compared performances of different algorithms for estimating annual nutrient loads discharged by the eutrophic River Loire, Hydrological Processes, 19(2), 429-444, 2005.

Moatar, F. and Meybeck, M.: The influence of contrasting suspended particulate matter transport regimes on the bias and precision of flux estimates, Science of the Total Environment, 370, 515-531, 2006.

Moosmann, L., Müller, B., Gächter, R., Wüest, A., Butscher, E., and Herzog, P.: Trend-oriented sampling strategy and estimation of soluble reactive phosphorus loads in streams, Water Resources Research, 41, W01020, doi:10.1029/2004WR003539, 2005.

Preston, S., Bierman, V. J., and Sillimann, S. E.: An evaluation of methods for the estimation of tributary mass loads, Water Resources Research, 25(6), 1379-1389, 1989.

Ramsey, M. H.: Sampling as a source of measurement uncertainty: techniques for quantification and comparison with analytical sources, Journal of Analytical Atomic Spectrometry, 13, 97-104, 1998. 
Reinelt, L. E. and Grimvall, A.: Estimation of nonpoint source loadings with data obtained from limited sampling programs, Enviromental Monitoring and Assessment, 21(3), 173-192, 1991.

Rekolainen, S., Posch, M., Kämäri, J., and Ekholm, P.: Evaluation of the accuracy and precision of annual phosphorus load estimates from two agricultural basins in Finland, Journal of Hydrology, 128, 237-255, 1991.

Robertson, D. M. and Roerisch, E. D.: Influence of various water quality sampling strategies on load estimates for small streams, Water Resources Research, 35, 3747-3759, 1999.

Ryding, S. O. and Rast, W. (Eds.): The control of eutrophication of lakes and reservoirs, Man and the Biosphere Series Vol 1, UNESCO and the Parathenon Publishing Group, 1989.

Standard methods for the examination of water and wastewater, American Public Health Association, American Water Works Association and Water Environment Federation (Eds.), 20th Edition, 1998.

Tonderski, A., Grimvall, A., Dojlido, J. R., and Van Dijk, G.: Monitoring nutrient transport in large rivers, Environmental Monitoring and Assessment, 34(3), 245-269, 1995.

Trudgill, S. T. (Ed.): Solute modelling in catchment systems, John Wiley, Chichester, 1995.

van Loon, E., Brown, J., and Heuvelink, G.: Methodological considerations, in: Guidelines for assessing data uncertainty in river basin management studies, edited by: van Loon, E. and Refsgaard, J. C., HarmoniRiB Report http://www.harmonirib.com/, 2005.

Vanoni, V. A.: Sedimentation engineering, American society of Civil Engineers, Manuals and Reports on Engineering practice No. 54, American Society of Civil Engineers, New York, pp. 154-190 and 317-349, 1977.
Vörös, L. and Padisak, J.: Phytoplankton biomass and chlorophylla in some shallow lakes in central Europe, Hydrobiologia, 215, 111-119, 1991.

Walling, D. E. and Webb, W. B.: The reliability of suspended sediment load data, Erosion and Sediment Transport Measurement, IAHS Publication No 133, IAHS Press: Wallingford, 177-194, 1981.

Walling, D. E. and Webb, W. B.: The reliability of rating curve estimates of suspended sediment yield: some further comments, Sediment budgets, in: IAHS Publication No 174, edited by: Boardas, M. P. and Walling, D. E., IAHS Press, Wallingford, 337-350, 1988.

Walling, D. E., Webb, W. B., and Woodward, J. C.: Some sampling conciderations in the design of effective strategies for monitoring sediment associated transport, Erosion and Sediment Transport Monitoring Programms in River Basins, in: IAHS Publication No. 210, edited by: Bogen, J., Walling, D. E., and Day, T. J., IAHS Press, Wallingford, UK, 279-288, 1992.

Wass, P. D. and Leeks, G. J. L.: Suspended sediment fluxes in the Humber catchment, UK, Hydrol. Process., 13, 935-953, 1999.

Webb, B. W., Phillips, J. M., Walling, D. E., Littlewood, I. G., Watts, C. D., and Leeks, G. J. L.: Load estimation methodologies for British rivers and their relevance to the LOIS RACS(R) programme, The Science of the Total Environment, 194-195, 379389, 1997.

WMO: Manual on operational methods of the measurements of sediment transport, Operational Hydrological Report No 29, Genf, 1989.

Worrall, F. and Burt, T. P.: A univariate model of river water nitrate times series, J. Hydrol., 214, 74-90, 1999. 